\title{
"Corruptive abuses of senior public officials in the banking sphere as a determinant of the Ukrainian economy criminalization"
}

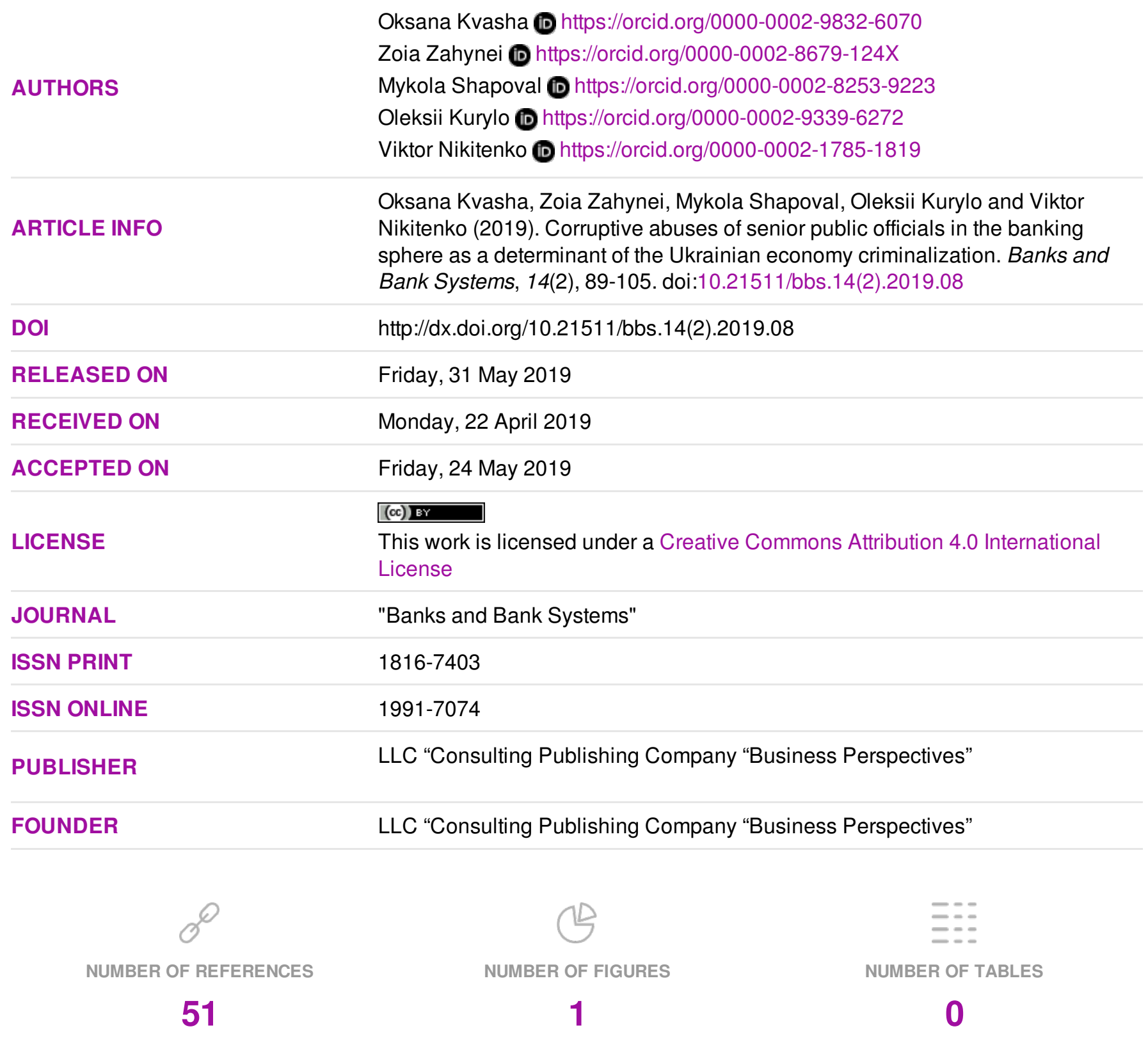

(c) The author(s) 2022. This publication is an open access article. 


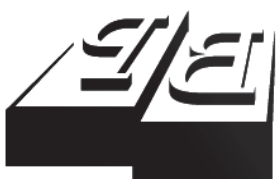

BUSINESS PERSPECTIVES

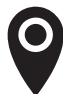

LLC "CPC "Business Perspectives" Hryhorii Skovoroda lane, 10, Sumy, 40022, Ukraine

www.businessperspectives.org

Received on: 22 $2^{\text {nd }}$ of April, 2019 Accepted on: $24^{\text {th }}$ of May, 2019

(C) Oksana Kvasha, Zoia Zahynei, Mykola Shapoval, Oleksii Kurylo, Viktor Nikitenko, 2019

Oksana Kvasha, Doctor of Law, Professor, Institute of State and Law, V. M. Koretsky National Academy of Sciences of Ukraine, Ukraine.

Zoia Zahynei, Doctor of Law, Associate Professor, Head of Department, the Posecutors Training in the Sphere of Corruption Counteraction, Institute of Prosecutor's Training of the National Prosecution Academy of Ukraine, Ukraine.

Mykola Shapoval, Ph.D. Student, Law Faculty, Sumy National Agrarian University, Ukraine.

Oleksii Kurylo, Ph.D. in Law, Sumy National Agrarian University, Associate Professor of the International Relations Chair, Ukraine.

Viktor Nikitenko, Ph.D. in Law, Researcher of the Department of Criminal Law, Criminology and Judiciary, the Institute of State and Law, V. M. Koretsky National Academy of Sciences of Ukraine, Ukraine.

\section{(c) (i)}

This is an Open Access article, distributed under the terms of the Creative Commons Attribution 4.0 International license, which permits unrestricted re-use, distribution, and reproduction in any medium provided the original work is properly cited.

Oksana Kvasha (Ukraine), Zoia Zahynei (Ukraine), Mykola Shapoval (Ukraine), Oleksii Kurylo (Ukraine), Viktor Nikitenko (Ukraine)

\title{
CORRUPTIVE ABUSES OF SENIOR PUBLIC OFFICIALS IN THE BANKING SPHERE AS A DETERMINANT OF THE UKRAINIAN ECONOMY CRIMINALIZATION
}

\begin{abstract}
The issues of crimes commission in the sphere of banking activity in Ukraine are highlighted. It is emphasized that crimes in banking activity are systematically committed by the public officials of the state. Such actions committed by the public officials cause the losses to the Ukrainian economy in the specially big amount. In the last two years, the socially dangerous consequences of these acts for the state economy are calculated by hundreds of millions of hryvnias. The defendants of these resonant criminal cases are the heads of banking institutions and senior public officials, as well as the officials of the National Bank of Ukraine. Moreover, the losses of these crimes cannot be compensated to the state economy, since the money laundered are placed for a long time in offshore areas outside the state. The conclusion is fomulated that current criminal legislation of Ukraine should be amended. First, there is the social need for criminalization of the socially dangerous actions committed by the public officials in banking sphere. Second, the study of the criminal legislation of the separate countries demonstrates that criminal liability of the legal persons for commission of the criminal offences in the sphere of banking activity is an effective measure to prevent the negative effects of the criminal threats. So this liability should also be introduced in Ukraine. Third, negligent crimes in the sphere of banking activities should also be criminalized, because an absence of such criminal prohibilion leads to the negligent behavior of the bank managers and to the socially dangerous results.
\end{abstract}

\section{Keywords}

\section{JEL Classification K14, K33, K42, G18, G21, G33}

\section{INTRODUCTION}

The activity of numerous public agencies in Ukraine, as well as banking institutions is utterly corrupted. Corruption is not only a method of enrichment of power structures, but also a management tool. Corruptive abuses, especially those committed at the highest level, represent one of the most pressing problems nowadays. Corruption-related abuses in the banking sphere of Ukraine are more likely to be the result of inefficient public management, but not its cause (Reanimation Package of Reforms, 2019, March). Complex mechanisms for implementation of crimes and involvement of a significant number of people thereto - from common employees, banking officers to management and senior public officials - suggest that the executors intentionally, selfconfidently and daringly implement their criminal intents and are not particularly thinking of responsibility. Corruption in modern Ukraine remains an important factor, which ensures functioning of a highly inefficient state apparatus and economy (Reanimation Package of Reforms, 2019, March). 
The crimes in the banking sphere related to official and professional activity in public service provision require a careful analysis alongside with other abuses in the sphere. Neither the criminal law theory, nor the practical domain offer a unified notion of an official crime in the banking sphere, and the mechanisms for commission of these crimes are understudied. The abuses in a banking institution commited by its management and other bank officers make its possible efficient functioning and provision of highlevel services to consumers more complicated. These categories of banking employees have a certain range of powers, through the execution of which they have to ensure stable and coordinated functioning of the banking units.

In exercising their powers, managers and representatives of top-management of the bank must form an integral managerial network of internal relations, which would ensure the most efficient functioning and minimize probability of occurrence of negative consequences of abuses. Within the context of comprehensive study of the abuses of office by senior officials in the banking sphere, there arises a need to focus on control, which is one of the management components. Control on the part of officials with relevant powers in the banking sphere shall ensure realization of supervisory function and reduce the risks of abuses.

The purpose of the article is to develop theoretical provisions, analyze the current state of commission of abuses of office in the banking sphere of Ukraine and identify consequential impact of these processes on the economic component of stability in the country.

Considering the above purpose, the following key objectivesthe are defined:

1) investigating the peculiarities (trends) of the modern state of commission of corruptive abuses in the banking sphere of Ukraine;

2) identifing the main defects of current legislation imposing liability for criminal offenses in the banking sphere and making suggestions on their elimination;

3) analyzing the best experience and provisions of current legislation of other states regarding organizational measures for the banking sphere protectionand liability for commission of corruptive abuses;

4) developing an authors' notion of official crimes in the banking sphere;

5) identifing the main subjects of prevention of official crimes in the banking sphere;

6) establishing prospective areas for counteraction and prevention of official crimes in the banking sphere;

7) formulating suggestions on improvement of the current legislation provisions of Ukraine concerning prevention of abuses of office in the banking sphere with due consideration of the best experience of other states.

The research methods were selected in considering the research objective and research tasks. Hence, the methodological principle of social naturalism was used in the establishment of criminogenic determination and social conditioning of the criminal and legal protection of the banking sphere. The methods of legal logic were used while formulating suggestions on improvement of the current legislation provisions in Ukraine concerning liability for abuses of office in the banking sphere. The comparative law method was used to analyze provisions of legislation of certain states governing liability for illegal acts in the banking sphere. Being committed at the macrolevel, the corruptive abuses of senior public officials constitute a special social danger, 
cause irreversible damage to the state economy, are calculated in extremely high indicators of losses worth millions and cannot actually be repaid to the state and its citizens due to the complex criminal schemes for legalization of money into the branched systems of offshore areas. The corruptive relations now more than ever displace legal and ethical relations between people and gradually transform from abnormality into a standard of conduct. Obraztsov (1982) was fair to mention the connection between official ("white-collar") and economic crimes: "The economic crimes form a separate class of crimes, the element of a more general classification level - the crimes associated with professional activity (Obraztsov, 1982, p. 101).

The notion of "official" is reflected in provisions of the current legislation of Ukraine. In particular, Part 3, Art. 18 of the Criminal Code of Ukraine (CCU) provides that the officials are those persons who are permanently, temporarily or expressly authorized to exercise functions of public officers or local government and hold permanent or temporary positions related to performing organizational and managerial or business and administrative functions with public authorities, local governments, enterprises, institutions and organizations or are expressly authorized to perform these functions by a competent public authority, local government, central government authority with a special status, competent authority or competent service of an enterprise, institution, organization, court, or law (Verkhovna Rada of Ukraine, 2001a). Nevertheless, the notion of official of the banking institution is somewhat different in its meaning as it is conditioned by the specific nature of banking activity.

Many researchers associate the issue of criminal liability for crimes in the banking sphere with liability for crimes in the economic sphere, the so called "economic crimes". For example, Dudorov (2003) suggested classification of crimes in the sphere of economic activity depending on the specific object and identified a separate classification group of crimes against rights and legal interests of creditors among them (Art. 218-222 of CCU) (Dudorov, 2003, p. 24). The other classifications were suggested by V. Ya. Tatsii, O. I. Perepelytsia, and V. M. Kyrychko. In the system of crimes in economic activity (with due consideration of decriminalized criminal and legal norms) depending on their specific object, they identified the classification groups of crimes in the sphere of credit and financial, banking and budgetary systems of Ukraine (Art. 199, 200, 201, 210, 211, 212, 212 ${ }^{1}, 204$ and 216 of CCU), as well as the group of crimes in the bancruptcy sphere (Art. 218, 219, 220 and 221 of CCU) (Stashysa \& Tatsiia, 2010).

Another classification of crimes in the credit and financial sphere was suggested by Larychev (1996). The scientist classified the crimes in the credit and banking sphere and associated them with the use of the following mechanisms by criminals:

1) cash and cashless settlement transactions: account opening transactions, settlements by payment orders, settlements with the use of payment request orders, settlements with the use of letters of credit, interbank settlements, account management transactions with the use of memorial slips;

2) currency transactions: foreign exchange transactions, import and export of currency values, retail trade and provision of services for foreign currency, currency transactions under foreign trade agreements;

3) credit transactions: active and passive;

4) securities market functioning (Larychev, 1996).

It is notable that the criteria of such classifications remain ambiguous, though their formulation is an important ground for developing separate methods for crime investigation.

What cannot be accepted is that the economic activity and banking activity are identical notions. This is due to the fact that the notion of "banking activity" covers only the activity defined in provisions of Art. 
- Collection and analysis of key performance indicators of an enterprise

- Improvement of the system
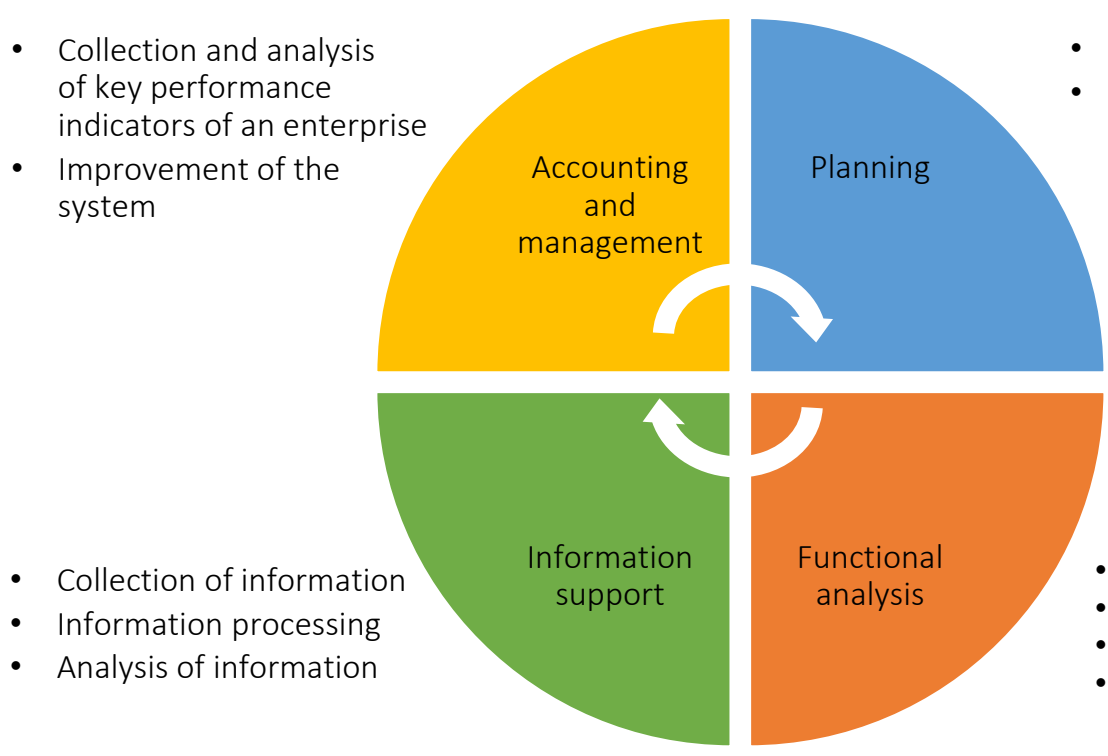

- Strategic planning

- Operational planning

Figure 1. Major control functions

2 of the Law of Ukraine "On Banks and Banking Activity", particularly: "The banking activity is the attraction of funds of individuals and legal entities to deposits and placement of the mentioned funds on own behalf, on own terms and at own risk, opening and management of bank accounts of individuals and legal entities" (Verkhovna Rada of Ukraine, 2001b).

Despite having a private component, the banking activity is of public nature. This is reflected in ensuring its content through legal activity - objectified, law-mediated, intellectual and volitional, managerial and other activity of the competent organized structures (Tuliai, 2010, p. 16). According to Mutsalov (2007), the notion of "crimes in the banking sphere" unites a group of acts aimed at infliction of damage to social relations, which develop in the course of the banking activity and infringing social relations in other spheres, but in some way or other inflicting damage to banking and credit institutions (Mutsalov, 2007, p. 40). The nonidentity of economic and bankng activities was also mentioned by Ulybina (2014) in her thesis research.

The value of social relations formed in the banking sphere alongside with property relations, relations formed in the sphere of economic activity, is caused by the fact that the functioning of the modern society is ensured due to the use of banking technologies and is associated with the stable functioning of the banking system.

The banking system stability (BSS) is characterized by reliability, balanced state and proportionate functioning of its structural elements, ability to preserve persistent balance and reliability for long periods of time (Uskov, 2013, p. 201). A stable banking system requires an efficient mechanism for implementing control of banking security on the part of officials charged with the primary managing and supervisory functions of top management (Korchenko, Skachek, \& Khoroshko, 2014, p. 185).

A broad spectrum of tasks of control and prevention of abuses requires implementing not only the classical functions of management, but also the analysis and monitoring of activity (see Figure 1).

The corruptive abuses in the banking sphere have an adverse effect upon stability of the state banking system. In particular, Stechyshyn mentions that the development of the entire banking system may depend on professionalism and efficiency of management of a particular banking institution. The scientist refers the bank management efficiency to the so called "internal factors", which impact the banking system stability (Stechyshyn \& Didyk, 2016, p. 811). 
Formation of an efficient system of criminal liability for corruption-related crimes in the banking sphere shall become a component of a long-term strategy aimed at reduction of possibilities for commission of corruptive offenses and increase of competition in the economic sphere.

\section{THEORETICAL BASIS}

Chuprova, while analyzing the issue liability for crimes in the economic sphere according to the criminal law of England, gives the following classification of crimes in the banking sphere:

- crimes committed by bank officers, shareholders, as well as companies carrying out banking activity without a relevant permission of the Bank of England and acting for the purpose of generation of additional income;

- crimes committed with the use of banks and banking technologies and tools for the purposes of personal profit;

- crimes associated with money laundering and other acts requiring violation of bank secrecy (Chuprova, 2007, p. 121).

According to Boiko and Kondratiev (2011), the crimes in the banking sphere may be conditionally divided into three main groups: crimes committed by organized groups consisting of either external persons or bank officers; crimes associated with the offence against property and funds of the bank or its clients; and crimes committed by the bank officials, including but not limited to the managers (Boiko \& Kondratiev, 2011).

Herasymov argues that it would make sense to perform an even higher level of abstracting in the structure of the mentioned groups and divide them in respect to the peculiarities of the subject of criminal offence. As a result, the following groups may be distinguished:

1) crimes committed by managers and other officials, officers of banking institutions;

2) crimes committed by bank officers in collusion with representatives of enterprises or other institutions and organizations; and
3) crimes infringing on financial resources of banks committed by other persons without participation of representatives of these financial institutions (Herasymov, 2018).

The classification suggested by Herasymov generates interest. According to the authors, it may be supplemented with a classification group for commission of abuses of office in the banking sphere by senior officials or statesmen or public figures in connection with the execution of their official duties.

The analysis of fundamental criminal-legal regulations for criminal-legal protection of the sphere of banking activity of the EU and other countries will allow to formulate suggestions on improvement of the criminal legislation of Ukraine in the given direction. At the criminal legislation level, the "improvement process" shall be basically limited to improvement of system of criminal-legal means aimed at ensuring security of certain social relations, to criminalization or decriminalization of certain acts.

Hence, all factors such as orientation of the general foreign policy of Ukraine to the European and Euro-Atlantic integration, need for adjustment of the national legislation in accordance with the world standards, democratization of social and political relations at both internal and international levels determine the timeliness of pursuance of comparative studies in different areas of law (Kamenskyi, 2010, p. 1).

The USA, as a state with a progressive economy, was one of the first to develop measures aimed at ensuring interests of consumers of banking services and creditors and established liability for corruptive abuses of officials. The criminal legislation of the USA contains the explanation of the term "public official". In particular, Title 18 of the US Code "Crimes and Criminal Procedure" includes Chapter 11 "Bribery, Graft, and Conflicts of Interest" with Section 201 "Bribery of Public Officials and Witnesses". According 
to this Section, the term "public official" means: Member of Congress, Delegate, or Resident Commissioner, either before or after such official has qualified, or an officer or employee or person acting for or on behalf of the United States, or any department, agency or branch of Government thereof, including the District of Columbia, in any official function, under or by authority of any such department, agency, or branch of Government, or a juror (Legal Information Institute (LII), 2012a).

For the purpose of the same Section, the term "person who has been selected to be a public official" means any person who has been nominated or appointed to be a public official, or has been officially informed that such person will be so nominated or appointed.

Other Sections of the US Criminal Code prescribe the liability for the following actions: "Offer of loan or gratuity to financial institution examiner" (Section 212) (LII, 2012b) and "Acceptance of loan or gratuity by financial institution examiner" (Section 213) (LII, 2012c). The interesting fact is the descriptive disposition of these criminal and legal norms as to the explanation of the term "examiner" who is the criminal offender. In particular, for the purpose of these Sections, the term "examiner" means any person appointed by a Federal financial institution, regulatory agency or pursuant to the laws of any State to examine a financial institution; or elected under the law of any State to conduct examinations of any financial institution.

The other sections of the US Criminal Code will also establish criminal liability for illegal acts of the persons who are somehow related to the banking acivity. For example, Chapter 11 of Title 18 of the US Code "Crimes and Criminal Procedure" includes Chapter 31 "Embezzlement and Theft" with the following Sections: "Theft by bank examiner" (Section 655); "Theft, embezzlement, or misapplication by bank officer or employee" (Section 656). According to the provisions of these Sections, the list of persons who can be liable for these crimes is clearly defined in the provisions of criminal-legal norms. Among these persons are: an officer, a director, an agent or an employee of, or connected in any capacity with any Federal Reserve bank, a member bank, a depository institution holding company, a national bank, an insured bank, a branch or an agency of a foreign bank, or organization operating under Section 25 or Section 25(a) of the Federal Reserve Act, or a receiver of a national bank, insured bank, branch, agency, or organization or any agent or employee of the receiver, or a Federal Reserve Agent, or an agent or employee of a Federal Reserve Agent or of the Board of Governors of the Federal Reserve System (LII, 2012d).

Moreover, as far back as in 1970 the USA passed the Bank Secrecy Act (BSA) in order to counteract illegal financial transactions related to money laundering and use of hidden accounts in foreign banks. The BSA contains requirements concerning control over every money transfer exceeding USD 10,000. Moreover, the document sets the standards, the violation of which shall result in civil or criminal liability. The state control over transactions performed by financial institutions of the USA shall also be ensured due to the branched network of organizations with relevant supervisory functions. Another stage aimed at anti-money laundering is the approval of the Money Laundering Control Act in 1986. In particular, three types of crimes in the sphere of money laundering may be distinguished in accordance with the above regulatory act: deliberate assistance in performance of transactions, which may be performed for money laundering purposes by officers of credit organizations; inducement of the third persons to laundering of large sums (over USD 100,000) derived from illegal activity; deliberate splitting up of money transfers in order to get around the BSA requirements.

Moreover, in 1986, the Money Laudering Control Act came into force, which set an obligation for credit organizations to perfrom work in accounting of all the primary documents in cashless transactions in the sphere of commerce and sevices, postal and telegraphic transfers as well as bank, cashier's and traveller's checks amounting to more than USD 3,000 (The Money Laundering Control Act, 1986).

The Financial Institutions Reform, Recovery and Enforcement Act of 1989 is the US Federal Act, according to which the governmental aid to bankrupt savings and loan associations was provided, significant changes in the system of supervision 
over these institutions were made and equity standards were strengthened. Pursuant to the provisions of the mentioned act, the Resolution Trust Corporation was formed for closure and merger of bankrupt associations. Also, the Resolution Funding Corporation was formed to accumulate the means of financing of closures and mergers of bankrupts in markets.

It may be stated that in contrast to the reforming of the banking system of Ukraine in 2014, which provided for the measures for liquidation of insolvent banking institutions and, consequently, job losses and a number of other adverse consequences, the USA provided governmental aid to bankrupt banking institutions or perfomed their closure and merger in a less stressful way.

Herewith, the indicators of crime in the banking sphere of the last years in the USA give a somewhat doubtful idea of efficiency of all the measures taken. In the first half-year of 2017, 791 offences in the banking sphere were registered in the USA as compared to 1,091 offences for the entire year 2016, which indicates a negative tendency (Moskalenko, 2014). There has been no tendency towards reduction of a number of crimes in the banking sphere in 2018. However, the indicators are considered to be generally acceptable for a country with an extensive territory.

A significant number of the criminal-legal norms of the People's Republic of China (PRC) is dedicated to protection of the banking sphere. For instance, according to Article 186 of the Criminal Code of the PRC, "any employee of a bank or of any other banking institution who, against laws or administrative rules and regulations, grants fiduciary loans or guaranteed loans to his connections on conditions that are more preferential than those for granting the same type of loans to other borrowers, thus causing relatively heavy losses, shall be sentenced to fixed term imprisonment of not more than five years or criminal detention and shall also be fined not less than 10,000 yuan but not more than 100,000 yuan; if heavy losses are caused, he shall be sentenced to fixed-term imprisonment of not less than five years and shall also be fined not less than 20,000 yuan but not more than 200,000 yuan" (Criminal Law of The People's Republic of China, 1997).
The interest is also borne by Article 174 of the Criminal Code of the PRC: "Unauthorized establishment of a commercial bank or another financial structure without the approval of the People's Bank of China”. Pursuant to the Law of Ukraine "On Introduction of Amendments to Certain Legislative Acts of Ukraine regarding the Humanization of Responsibility for Violations in the Sphere of Economic Activity" No. 4025-VI, Art. 202 of the CCU "Violation of Procedure for Practicing Economic Activity and Provision of Financial Services" was decriminalized. According to the authors, the reasonability of decriminalization of the latter is questionable.

Article 174 of the Criminal Code of the PRC states: "Whoever establishes a commercial bank or any other banking institution without the approval of the People's Bank of China shall be sentenced to fixed-term imprisonment of not more than three years or criminal detention and shall also, or shall only, be fined not less than 20,000 yuan but not more than 200,000 yuan; if the circumstances are serious, he shall be sentenced to fixed-term imprisonment of not less than three years but not more than 10 years and shall also be fined not less than 50,000 yuan but not more than 500,000 yuan" (Criminal Law of The People's Republic of China, 1997). Production of a false permit of a commercial bank or other financial structure, its forgery or transfer for use to a third person shall be penalized in accordance with Part 1, Art. 174 of the Criminal Code of the PRC.

As is the case in many European states, the Criminal Code of the PRC provides for the liability of collective subjects for commission of certain offences. In particular, Art. 174 of the Criminal Code of the PRC states: "Whoever forges, alters or transfers the permit for operation of a commercial bank or any other banking institution shall be punished in accordance with the provisions of the preceding paragraph. Where a unit commits any of the crimes mentioned in paragraph 1 of 2 of the Art. 174, it shall be fined, and the persons who are directly in charge and the other persons who are directly responsible for the crime shall be punished in accordance with the provisions of the first paragraph" (Criminal Law of The People's Republic of China, 1997). 
There is also the experience in the issues of liability of collective subjects for commission of crimes in the EU. Article 3 of the Law of the Republic of Poland "On Liability of Collective Subjects for the Acts Prohibited under the Penalty of Perjury" as of October 28, 2002 defines unlawful conduct of an individual who:

1. acts for or on behalf of a collective subject within the authorities or duties concerning his representation, making decisions on his behalf or implementation of internal control or in case of abuse of the delegated authorities or undue performance of obligations imposed on the individual;

2. acts in excess of his powers or unduly performs his obligations;

3. acts for or on behalf of a collective subject with the consent or with the knowledge of the person mentioned in Clause 1 of this Article;

4. is an entrepreneur, as a ground for criminal liability of a legal entity (Criminal Code of the Republic of Poland, 1997, p. 83).

Another common feature of the EU legislation is the evidence that the criminal acts shall be committed in the interests and to the benefit of a legal entity. Article 5 of the Criminal Code of Belgium states that legal entities are subject to criminal liability for the crimes committed to obtain benefits (Criminal Code of the Kingdom of Belgium, 2016, p. 83, 89). In the Criminal Code of Ukraine, the crimes in the banking sphere are mostly characterized with a lucrative motive.

In the CCU, the crimes committed in the banking sphere, for which the criminal-legal measures may be taken against legal entities, are set forth in Article 209 "Legalization (laundering) of criminally obtained money". Pursuant to the Law of Ukraine "On Introduction of Amendments to Certain Legislative Acts of Ukraine regarding the Implementation of the Action Plan for Liberalization of the Visa Regime for Ukraine by the European Union concerning Liability of Legal Entities", the CCU was supplemented with the Section XIV-1 "Criminal-Legal Measures against Legal Entities", whose provisions define the commission of any crime set forth in Art. 96 of the CCU by an authorized person of a legal entity or under instruction or by order, in collusion and in complicity or otherwise for or on behalf of a legal entity as a ground for application of the criminal-legal measures against a legal entity". These crimes shall include Art. 209 of the CCU.

The Criminal Code of Finland contains an entire set of criminal-legal norms concerning legalization (laudering) of money, which in certain cases may be qualified collectively with the crimes in the banking sphere and official activity. In particular, Chapter 32 of the Criminal Code of Finland "Receiving and money laundering offences" includes the following criminal-legal norms:

- "Money laundering" (Section 6);

- “Aggravated money laundering” (Section 7);

- "Conspiracy for the commission of aggravated money laundering" (Section 8);

- "Negligent money laundering" (Section 9);

"Money laundering violation" (Section 10).

The legislature of Finland establishes criminal liability even for the negligent legalization of criminally obtained money. This is absolutely unusual for the legislature of Ukraine.

Also, the separate Chapter of the CC of Finland is devoted to the offences committed in office. Chapter 40 of the CC of Finland "Offences in office" includes the following kinds of the criminal-legal norms:

“Acceptance of a bribe" (Section 1);

"Aggravated acceptance of a bribe" (Section 2);

"Bribery violation" (Section 3);

"Acceptance of a bribe as a member of Parliament" (Section 4);

"Aggravated acceptance of a bribe as a member of Parliament" (Section 4a); 
- "Breach and negligent breach of official secrecy" (Section 5);

- "Abuse of public office" (Section 7);

- "Aggravated abuse of public office" (Section 8);

- "Violation of official duty" (Section 9);

- "Negligent violation of official duty" (Section 10).

Positive feature of the CC of Finland is clear definition of the terms (criminal offenders). For example, for the purposes of Chapter 40 of the CC of Finland: a public official refers to a person who serves in an office or in a comparable position of service in respect of the state, a municipality or an association of municipalities or of a co-operative body under public law of municipalities, Parliament, a state-owned company or the Evangelical Lutheran Church or the Orthodox Church or its parish or a co-operative body among parishes, the province of Åland, the Bank of Finland, the Social Insurance Institution, the Institute of Occupational Health, a municipal pension institution, the Municipal Surety Centre or a municipal labor market office (The Criminal Code of Finland, 2015). Other clear explanations in this chapter are given to the following terms: a person elected to a public office; an employee of a public corporation; a foreign public official; a person exercising public authority; a member of a foreign Parliament.

Article 112 of the CCU "Trespass against life of a statesman or a public figure" provides for an exhaustive list of persons belonging to the category of statesmen or public figures. In particular, these include: the President of Ukraine, the Chairman of the Verkhovna Rada (Parliament) of Ukraine, a National Deputy (Member of Parliament) of Ukraine, the Prime Minister of Ukraine, a member of the Cabinet of Ministers of Ukraine, the Chairman or a judge of the Constitutional Court of Ukraine or the Supreme Court of Ukraine or High Specialized Courts of Ukraine, the Procurator General of Ukraine, the Human Rights Commissioner of the Verkhovna Rada of Ukraine, the Head of the Accounting Chamber, the Chairman of the National Bank of Ukraine, or a leader of a political party (Legal services Online).
Subject to the provisions of Part 3, Art. 18 and Art. 112 of the CCU, it is possible to define senior public officials of the state (statesmen or public figures) as the subjects of certain corruptive abuses in the banking sphere.

\section{RESULTS}

The examination of the content of the criminal-legal norms establishing liability for official crimes in the banking sphere of Ukraine and other states allowed to define their concept. According to provisions of the current criminal legislation of Ukraine, these shall include the totality of intentional socially dangerous acts aimed at acquisition of financial resources of banking institutions or their clients, which may be performed in the course or with the use of banking transactions by the criminal subjects in the banking sphere with misuse of their official position.

The analysis of the selected criminal cases made it possible to find out that the abuses of office in the banking sphere are committed by certain categories of persons. In particular, it was established that the subjects of commission of these crimes include:

1) senior managing employees of the banks, branch and department managers;

2) other categories of bank employees and bank officials;

3) statesmen or public figures (senior officials).

The criminal legislation of Ukraine does not effectively address the subject matter of crimes committed in the banking sphere. The studies dedicated to the problems of the special subject of a crime and competition of the criminal-legal norms state that the specific subjects are also the special subjects, but their features are largely detalized in terms of the defined elements of crime (Marin, 2001, p. 128; Dudorov, 2009, p. 9). Hence, the subjects of crimes in the banking sphere may include: bank managers, bank officials, related parties. Herewith, as defined by the NBU, a related party is an individual who is related to activity and management of the bank due to her official status, family ties or prop- 
erty status and may get certain material benefits in the process of performance of its functions by the bank. The related parties may include:

1) bank managers;

2) substantial shareholders of the bank;

3) close relatives, husbank, wife, children, parents of a manager or substantial shareholder of the bank;

4) affiliated persons of the bank, managers and substantial shareholders of the affiliated entitites as well as their close relatives (Glossary NBU).

Pursuant to Part 2 of the Note to Art. 218 of the CCU, the interpretation of the notion "related party" requires a reference to provisions of the Law of Ukraine "On Banks and Banking Activity". The existence of criminal-legal norms with blanket dispositions results in the number of features of the elements of crime being determined not only by the Criminal Code, but also by other regulatory acts which do not constitute the law on criminal liability (Dudorov, 2009). Saienko states that they actually allow the NBU to supplement the list of related parties at its own discretion based on subjective factors, particularly - with consideration of a shadowy phrase "nature of relations and connections with a bank". Respectively, the NBU will determine criteria for allocation of certain market participants to the list of the related parties alongside with the performance of functions of supervision over the bank transactions with the related parties, which would create a favorable ground for various manipulations and corruptive abuses, which everyone tries to combat so defiantly (Saienko, 2015). This means that the subjective elements of crime in the banking sphere of Ukraine require maximum clarification.

Moreover, the typical methods of commission of crimes by senior officials of Ukraine were determined. Particularly, these include misappropriation, embezzlement or conversion or property by malversation (Art. 191 of the CCU) and legalization (laundering) of criminally obtained money (Art. 209 of the CCU).
The implementation of these methods of criminal activity is described in the following example. The Department for International Legal Cooperation of the Prosecutor's General Office of Ukraine held an investigation on S. V. Kurchenko suspicion of participating in the criminal organization of the former President of Ukraine V. F. Yanukovych and commission of the following serious crimes against Ukraine as part of this organization:

- repeated misappropriation of another's property - the funds of the NBU for the amount of UAH 787,396,148.99 provided as a stabilization loan by Real Bank PJSC with subsequent legalization (laudering) of the criminally obtained money - through misuse of official powers and official forgery of documents by officials;

repeated misappropriation of another's property - the funds of Real Bank PJSC on an especially large scale in the amount of UAH $4,707,267,476.52$ in the provision of loans to the enterprises under control of S. V. Kurchenko bearing the features of fraudulence with subsequent legalization (laundering) of the criminally obtained money - through misuse of official powers and official forgery of documents by officials;

repeated misappropriation of another's property - the funds of Brokbiznesbank JSC for the total amount of UAH $865,879,925.97$ by way of illegal provision of interbank credits by Brokbiznesbank JSC for the benefit of Real Bank PISC and illegal allocation of funds on correspondent account in Real Bank PJSC by Brokbiznesbank JSC with subsequent legalization (laundering) of the criminally obtained money - through misuse of official powers and official forgery of documents by officials;

- repeated misappropriation of another's property - the funds of Brokbiznesbank JSC for the total amount of UAH $1,436,723,153$ by way of provision of loans to the enterprises bearing the features of fraudulence in violation of requirements of the current legislation of Ukraine with subsequent legalization (laundering) of the criminally obtained money - through misuse of official powers and official forgery of documents by officials; 
- repeated misappropriation of another's property - the funds of Ukrgazbank JSB for the total amount of UAH 502,311,170.64 by way of conclusion of fictitious agreements for purchase and sale of securities - bonds of the State Mortgage Institution - between Ukrgazbank JSB and the State Mortgage Institution with subsequent legalization (laundering) of the criminally obtained money - through misuse of official powers and official forgery of documents by officials;

- repeated misappropriation of another's property - the funds of Ahrarnyi Fond JSC for the total amount of UAH 2,069,194,000 by way of conclusion of fictitious agreements for purchase and sale of the bonds of internal public loan between Brokbiznesbank JSC and Ahrarnyi Fond JSC and direct REPO agreements with the NBU with subsequent legalization (laundering) of the criminally obtained money - through misuse of official powers and official forgery of documents by officials;

- repeated fictitious entrepreneurship, i.e. formation and acquisition of business entities (legal entitites), for the purpose of covering of illegal activity, which inflicted major material damage.

The criminal proceedings against 42 persons from among those persons notified of suspicion were referred for examination of the merits to court. Following the results of examinations, 27 indictments were approved and four persons were released from liability by court due to the expiry of limitation for the institution of criminal proceedings. Court examinations against 15 persons are pending. The total value of the seized property makes over UAH 5 billion, the total amount of the recovered losses makes over USD 1.5 billion (Censor.net, 2019, March).

Another example with at least the same high profile is represented by the criminal proceeding against the former Governor of the National Bank of Ukraine V. Hontarieva and the co-owner of Investment Capital Ukraine (ICU) M. Paseniuk due to probable negligence regarding repayment of UAH 150 billion to the clients of the banks declared insolvent, initiated by the National AntiCorruption Bureau of Ukraine (NABU) in ear- ly 2019. The criminal case was qualified under Article 367 of the CCU "Neglect of Duty". The criminal proceeding was initiated by court order on a comlaint of the deputee of the Verkhovna Rada of Ukraine V. Kuprii.

According to the previous version of the NABU, senior officials V. Hontarieva, M. Paseniuk and Yu. Lutsenko committed acts regarding repayment of deposits of individuals of fictitiously bankrupt banks from the state budget for the amount over UAH 150 billion through misuse of their official duties, which could have caused negative consequences (Finance.ua, 2019).

As it can be seen from the above example, the crimes in the banking sphere committed by senior public officials (statesmen or public figures) are usually characterized by major losses on an especially large scale. The consequences of these crimes are expressed in not only infliction of major damages to certain persons, but also in violation of the banking system stability in the country and destabilization of the state economic system in general.

The activity of the NBU in the anti-corruption context was as well aimed at identification of the methods of commission of corruptive abuses on the part of managing and other officials of the banking institutions and management of their consequences. The banking institutions usually involve free savings of depositors with their further allocation among enterprises and private individuals requiring the debt funds. Nevertheless, it was established that officials of certain banking institutions in Ukraine used the following methods of commission of power abuses:

- the attracted funds of depositors were mostly used for cheap crediting of "non-banking" business of bank owners;

- the credits were usually extended at the rates below market rates and, as a rule, without any credit security;

- very often, non-liquid objects (such as a stadium) or securities of the companies with a formal "market" value but no property were extended against pledge; 
- another option was the use of a "friendly" appraiser, which could result in a sharp rise of the actual pledge value;

- the credits were often extended to "dummy" companies which, as in the previous case, had no own property (Seredniak, 2018, p. 68).

Under these conditions during the economic slowdown a conflict of interest arose between the bank owner and the depositors, which resulted in initiating a great number of criminal cases in order to ensure interests of consumers of bank services.

The analysis of other methods for commission of crimes in the banking sphere demonstrates that these can be characterized with such acts of the criminal subjects in the banking sphere, including but not limited to:

- promisory notes transactions, including the appropriation of payments under promissory notes;

- misappropriation of amounts from the bank clients' accounts;

- unreasonable understatement of the credit use interest amount;

- transfer of the bank funds under trust or extension of unsecured credits to business entitites related corruptively to the bank managers and officials;

- corruptive acts related to the extension of the credit period;

- illegal release of property.

The employees of accounting departments as the persons involved into accounting of banking operations may commit crimes by way of illegal debiting of funds from accounts.

A popular method of commission of crimes in crediting is the receiving of illegal aid. It is namely by suggestion of unlawful advantage that the issue of extension of credit to business entities having no legal grounds for this or the issue of easy credit terms are resolved. Another popular method to commit crimes in the banking sphere consists in the acts related to intentional delays in transfer of funds of the bank clients for the purpose of their use for own transactions in the currency exchange market.

Either practicians or scientists gave different definitions of the phenomenon of corruption. Nevertheless, the article uses the definition of this term set forth in Part 1, Article 3 of the Law of Ukraine "On Prevention of Corruption" as a basis (Kurylo et al., 2017). In order to establish the content of the term "official", it is necessary to proceed from the provisions contained in Part 3, Article 18 of the CCU as well as the Note to Art. 364 of the CCU.

The establishment of the range of persons committing the abuses of power in the banking sphere, the analysis of methods for implementing criminal abuses allowed to determine the principal reasons facilitating the increase in the level of crimes in the banking sphere committed by officials as well as senior officials classified as statesmen or public figures. These grounds, particularly, include:

1) undue check of potential employees of banking institutions in the course of employment process by authorized persons;

2) reinforcement of activity of organized criminal groups in collusion with officials and management of banking institutions;

3) gaps in the current legislation regarding the regulation of powers of employees and officials with regard to undue performance of their functional duties in a certain sphere;

4) personal motives of dishonest employees of banking institutions and related parties conditioned by the possibility to get substantial funds in case of daily access to these funds;

5) high latency of these crimes;

6) undue level of professional training of law enforcement officials concerning the detection of such offences;

7) lack of the security criminal-legal norms, which would ensure a high level of criminal li- 
ability for managers and senior officials (statesmen and public figures) for their unlawful acts committed on a large and an especially large scale, which caused socially dangerous consequences for the state economy, in the criminal legislation of Ukraine;

8) lack of the norms regarding the liability of managers as well as senior officials (statesmen and public figures) for their omission to act and failure to take relevant measures to prevent crimes in the banking sphere in the criminal legislation of Ukraine.

The CCU does not duly regulate the issue of liability of legal entities for commission of crimes in the banking sphere. Though, the criminal legislation of other states provides for this type of criminal and legal prohibitions. In particular, Article 174 of the
Criminal Code of the PRC establishes liability of legal entities in case of commission of illegal acts in the banking sphere. This practice exists in the legislation of Belgium and Poland as well as other European states. In the $\mathrm{CCU}$, the crimes committed in the banking sphere, for which the criminal-legal measures may be applied against legal entities, are set forth in Article 209 of the CCU "Legalization (laundering) of criminally obtained money".

The experts in legal practice in the European states, particularly in Italy (Giovanni Paolo Accinni e Associati, Baccaredda Boy) and Germany (Rettenmaier and Adick, Galen Rechtsanwälte) generally speak on the notion "banking criminal law", meaning the set of criminal offences committed in the banking sphere and practical mechanisms for resolution of issues of the relevant category.

\section{DISCUSSION AND CONCLUSIONS}

Despite the obviousness of criminogenic situation in the banking sector in Ukraine, there are virtually no studies of the problems of criminal and legal protection of banking activities (Klochko, Kurilo, \& Zapara, 2017). The abuses of public office in the banking sphere result in irreversible negative consequences for the economy of Ukraine. The lack of proper legislative regulation of commission of the abuses of public office in the banking sphere results in activation of these processes at the highest state level, irresponsible attitude of the authorized persons to performance of their duties, impunity and development of corruption. The problem of corruptive abuses in the banking sphere may be resolved through implementing a set of measures to minimize their manifestations. An efficient control system as part of the management system, which would allow not only to timely detect the abuses of public office but also to operatively adjust the organizational and management activity for the purpose of minimization of economically unreasonable costs, may become one of the methods of implementation of such measures. The continuity and flexibility of this management approach will require the availability of a controlling component, which would be aimed at efficiency of activity and facilitation of bank development at every management level.

The analysis of modern law enforcement practice in the banking sphere made it possible to formulate a number of rule-making problems which are to be solved first:

a) increase of the level of technical excellence of certain criminal-legal prohibitions in the banking sphere; and

b) additional orientation of the criminal legislation of Ukraine to the best foreign practices.

The prevention of the abuses of public office in the banking sphere shall be implemented in the form of organization of various types of preventive measures at different social management levels. The efficiency of prevention of the public office abuses in the banking sphere shall be ensured using the systemic measures. In particular, it goes about the measures of legislative and law enforcement nature as well as the set of measures aimed at minimization of manifestation of the public office abuses, which should have been ensured by management of banking institutions. 
In Ukraine, there is a rather successful system of control over compliance of banking transactions with law as well as abuses in the banking sphere. The key subjects of the system are the managers of banking institutions, the National Bank of Ukraine, the State Financial Monitoring Service of Ukraine, and the National Anti-Corrution Bureau of Ukraine.

In particular, the aim of the Internal Audit Department of the NBU is to assess the efficiency of risk management processes, internal control and performance of managerial functions ensured by the structural units of the NBU (2018). The bank manager shall ensure timely provision upon request of accurate information, materials, documents, explanations in the established form, structure, scope, format, according to the established procedure and within the established terms as well as to hold other activities set forth in the Regulation on the Procedure for Organization and Checking regarding the Issues of Prevention and Combatting of Legalization (Laundering) of the Criminally Obtained Money, Terrorism Financing and Financing of Proliferation of Weapons of Mass Destruction (NBU, 2011). The aim of the State Financial Monitoring Service is to take measures regarding the issues of prevention and combatting the manifestations of corruption at different levels (The State Financial Monitoring Service of Ukraine, n. d.). The National Anti-Corruption Bureau of Ukraine is a state law enforcement agency with the key objective of preventing, exposing, stopping, investigating and solving corruption-related offences committed by high officials, and averting new ones (NABU, 2014). The National Agency on Corruption Prevention as a central executive authority with a special status ensures the formation and implementation of the national anti-corruption policy.

Despite the functioning of the system of corruptive abuses prevention, which is, at the first sight, successfully formed, the official corruptive abuses are systematically committed by managers of banking institutions, bank officials as well as senior public officials.

In this regard, it was concluded on the necessity to improve provisions of the current criminal legislation of Ukraine in terms of establishment of liability for abuses of office in the banking sphere. Ensuring the criminal law protection of banking is a matter of great importance for world companies and even rating agencies (Kurylo et al., 2017, p. 115).

The criminal legislation of Ukraine lacks terminological certainty in the criminal-legal norms establishing liability for crimes in the banking sphere. Moreover, the subjective elements of crime do not receive sufficient attention as well. The current legislation of Ukraine does not provide any explanations concerning the "range of officials of banking institutions". The main problems in application of current criminal-legal norms of Ukraine on liability for crimes in the banking sphere are first of all conditioned by legislative defects.

With a view to the social conditioning of criminalization of socially dangerous acts, the criminalization of the act "Abuses of powers in the banking sphere" is evident. It is necessary to establish criminal liability of bank managers and other officials as well as senior public officials (statesmen or public figures) for the use of their powers contrary to legal interests of a banking institution for lucrative or other personal interest in case such act inflcted major material damage to the public, creditor or state.

It should also be mentioned that the current CCU does not classify the infringements on social relations in the banking sphere committed by negligence as criminal. Nevertheless, numerous bankruptcies, financial pyramides and other similar abuses with which the banking sphere is filled, suggest an idea that apart from immediate perpetrators of these crimes, the other persons shall be held liable (particularly, managers, officials of baking institutions as well as senior public officials (statesmen or public figures)) who had not ensured the due level of control at certain stage of commission of crime by their omission to act. In this regard, the criminalization of the act "Neglect of duty in the banking sphere" is required as well. 
The analysis of criminal legislation of certain states proves the efficiency of application of the criminallegal means against legal entities for their abuses of powers in the banking sphere as this act is a corruptive one. Subject to Art. 96 of the CCU, the commission of the act by the authorized person for or on behalf of the legal entity is a ground for application of the criminal-legal measures against the legal entity. With a view to the fact that the current criminal legislation of Ukraine establishes application of the criminal-legal measures against legal entities for commission of corruptive offences by the authorized person for or on behalf of the legal entity, it is necessary to extend the range of crimes set forth in Art. 96 of the CCU by the norm on the abuse of powers in the banking sphere.

The banking sphere in Ukraine is protected at a certain level and certain, though minor, indicatos of legislative activity in this direction may be observed lately. Nevertheless, the experience of other states proves that Ukraine has sufficient resources in order to improve provisions of criminal legislation, particularly, in terms of liability for corruption-related crimes in the banking sphere.

\section{ACKNOWLEDGEMENT}

The article is prepared as a part of the project for young scientists of Ukraine of 2017 (project registration number - $0117 \mathrm{U}$ 006531) "Improvement of the legislation of Ukraine as to the provision of the protection of the banking in the conditions of European integration: economic and legal aspect", by Alyona M. Klochko, Ph.D. in Law, Sumy National Agrarian University, Head of the Chair of International Relations.

\section{REFERENCES}

1. Baccaredda Boy. Law firm. (2003). Banking criminal law and finance criminal law. Retrieved from https://www. studiolegalebaccaredda.it/eng/pabanking-criminal-law.php

2. Boiko, I., \& Kondratiev, V. (2011). Щодо злочинів у банківській сфері та їх ефективного розслідування [Shchodo zlochyniv u bankivskii sferi ta yikh efektyvnoho rozsliduvannia]. Retrieved from http://www. rusnauka.com/12_ENXXI_2011/ Pravo/12_85717.doc.htm

3. Censor.net. (2019, March). Генеральна Прокуратура України завершила розслідування у справі Курченка. Про підозру повідомлено 98 особам [Heneralna Prokuratura Ukrainy zavershyla rozsliduvannia $u$ spravi Kurchenka. Pro pidozru povidomleno 98 osobam]. Retrieved from https://censor. net.ua/ua/news/3119125/gpu_ zavershyla_rozsliduvannya_u_ spravi_kurchenka_pro_pidozru_ povidomleno_98_osobam_ lutsenko
4. Chuprova, E. P. (2007).

Ответственность за экономические преступления по уголовному праву Англии [Otvetstvennost za ekonomicheskye prestuplenyia po ugolovnomu pravu Anhlii] (208 p.). Moscow: Volters.

5. Criminal Code of the Kingdom of Belgium. (2016). Retrieved from https://www.legislationline. org/download/action/download/ id/6365/file/Belgium_CC_1867_ am2016_fr.pdf

6. Criminal Code of the Republic Poland. (1997). Retrieved from https://www.legislationline.org/ download/action/download/ id/7354/file/Poland_CC_1997_ en.pdf

7. Criminal Law of The People's Republic of China. (1997). Retrieved from https://www.ilo. org/dyn/natlex/docs/ELECTRO NIC/5375/108071/F-78796243/ CHN5375\%20Eng3.pdf

8. Dudorov, O. О. (2003). Злочини у серері господарської діяльності: кримінально-правова характеристика: монограбія [Zlochyny u sferi hospodarskoi diialnosti: kryminalno-pravova kharakterystyka: monohrafiia] (24 p.). Kyiv: Yurydychna praktyka.

9. Dudorov, O. О. (2009). Про місце бланкетної диспозиції кримінально-правової заборони у конкретизації змісту складу злочину [Pro mistse blanketnoi dyspozytsii kryminalno-pravovoi zaborony u konkretyzatsii zmistu skladu zlochynu]. Visnyk Akademii advokatury Ukrainy, 1, 257-260. Retrieved from http://nbuv.gov.ua/ UJRN/vaau_2009_1_44

10. Finance.ua. (2019). НАБУ відкрило справу в зв'язку з можливою недбалістю при поверненні 150 млрд грн клієнтам банків [NABU vidkrylo spravu $v$ zviazku $z$ mozhlyvoiu nedbalistiu pry povernenni 150 mlrd hrn kliientam bankiv]. Retrieved from https://news.finance.ua/ua/ news/-/443638/nabu-vidkrylospravu-v-zvyazku-z-mozhlyvoyunedbalistyu-pry-povernenni-150mlrd-grn-kliyentam-bankiv

11. Galen Rechtsanwälte. Law firm. (n. d.). Banking and capital markets criminal law. Retrieved from 
http://www.galen.de/areas-of-law/ banking-criminal-law-capitalmarkets-criminal-law/

12. Giovanni Paolo Accinni e Associati. (2018). Law Firm. Retrieved from http://www.studioaccinni. com/banking-criminal-law-en. htm

13. Glossary NBU. (n. d.). Пов'язана ocoбa [Poviazana osoba]. Retrieved from http://bank.gov.ua/ control/uk/publish/article?art_ $\mathrm{id}=123539$

14. Herasymov, O. V. (2018). Banking Crime Counteraction (Ph.D. Thesis). V. N. Karazin Kharkiv National University, Kharkiv.

15. Hryshchuk, V. K., \& Pasieka, О. F. (2013). Кримінальна відповідальність юридичних осіб: порівняльно-правове дослідження: монографія [Кrуmіnalna vidpovidalnist yurydychnykh osib: porivnialno-pravove doslidzhennia: monohrafiia] (248 p.). Lviv: Lvivskyi derzhavnyi universytet vnutrishnikh sprav.

16. Investment Capital Ukraine (ICU). (2006). Retrieved from https:// www.icu.ua/en/about-icu/aboutus

17. Kamenskyi, D. V. (2010) Кримінальна відповідальність за податкові злочини за федеральним законодавством США [Kryminalna vidpovidalnist za podatkovi zlochyny za federalnym zakonodavstvom SShA] (Ph.D. Thesis).

18. Klochko, A. N., Kurilo, N. P., \& Zapara, S. I. (2017). К вопросу уголовно-правовой охраны сферы банковской деятельности Украины [K voprosu ugolovnopravovoy okhrany sfery bankovskoy deyatelnosti Ukrainy]. Vserossiyskiy kriminologicheskiy zhurnal, 11(4), 833-843. Retrieved from http://cj.bgu.ru/reader/article.aspx?id=21877

19. Korchenko, A. O., Skachek, L. M, \& Khoroshko, V. O. (2014). Банківська безпека [Bankivska bezpeka] (185 p.). Kyiv.

20. Kurylo, M., Klochko, A. Timchenko, G., \& Gulyk, A. (2017). Banking in Ukraine as an object of criminal and legal protection. Banks and Bank Systems, 12(4), 114-120. http://dx.doi.org/10.21511/ bbs.12(4).2017.11

21. Larychev, V. D. (1996). Преступления в кредитноденежной системе и противодействие им [Prestupleniya $v$ kreditnodenezhnoy sisteme $i$ protivodeystviye im](pp. 75-168). Moscow: YNFRA.

22. Legal Information Institute (LII) (2012a). Bribery of public officials and witnesses. In U.S. Code (para. 201). Retrieved from https:// www.law.cornell.edu/uscode/ text/18/201

23. Legal Information Institute (LII). (2012b). Offer of loan or gratuity to financial institution examiner. In U.S. Code (para. 212). Retrieved from https://www.law.cornell.edu/ uscode/text/18/212

24. Legal Information Institute (LII) (2012c). Acceptance of loan or gratuity by financial institution examiner. In U.S. Code (para. 213). Retrieved from https://www.law. cornell.edu/uscode/text/18/213

25. Legal Information Institute (LII) (2012d). Theft, embezzlement, or misapplication by bank officer or employee. In U.S. Code (para. 656) Retrieved from https://www.law. cornell.edu/uscode/text/18/656

26. Legal services Online. (n. d.). Коментар до статті 112 Посягання на державного чи громадського діяча [Komentar do statti 112. Posiahannia na derzhavnoho chy hromadskoho diiacha]. Retrieved from http:// yurist-online.com/ukr/uslugi/ yuristam/kodeks/024/110.php

27. Marin, О. К. (2001). Конкуренція кримінально-правових норм [Konkurentsiia kryminalnopravovykh norm] (Ph.D. Thesis) (232 p.). Lviv.

28. Moskalenko, N. V. (2014). Досвід США щодо побудови системи запобігання та протидії легалізації доходів, отриманих злочинним шляхом [Dosvid SShA shchodo pobudovy systemy zapobihannia ta protydii lehalizatsii dokhodiv, otrymanykh zlochynnym shliakhom]. Fynansy, uchet, banky, 1(20), 211.
29. Mutsalov, S. S. (2007). Уголовноправовые и криминологические меры противодействия преступлениям, совершаемым в сфере банковской деятельности [Ugolovno-pravovyye i kriminologicheskiye mery protivodeystviya prestupleniyam, sovershayemym $v$ sfere bankovskoy deyatelnosti] (Ph.D. Thesis) (206 p.). Grozny.

30. National Anti-Corruption Bureau of Ukraine (NABU). (2014). Зміст та принциии діяльності [Zmist ta pryntsypy diialnosti]. Retrieved from https://nabu.gov.ua/ zmist-ta-pryncypy-diyalnosti

31. NBU. (2011). Положення про порядок організаиії та проведення перевірок з питань запобігання та протидіi тегалізації (відмиванню) доходів, одержаних злочинним шляхом, фінансуванню тероризму та фінансуванню розповсюдження зброї масового знищення [Polozhennia pro poriadok orhanizatsii ta provedennia perevirok z pytan zapobihannia ta protydii lehalizatsii (vidmyvanniu) dokhodiv, oderzhanykh zlochynnym shliakhom, finansuvanniu teroryzmu ta finansuvanniu rozpovsiudzhennia zbroi masovoho znyshchennia]. Retrieved from https://zakon.rada.gov.ua/laws/ show/z0852-11/ed20170727\#n16

32. NBU. (2018). Основні функції структурних підрозділів Національного банку [Osnovni funktsii strukturnykh pidrozdiliv Natsionalnoho banku]. Retrieved from https://bank.gov.ua/doccata$\log /$ document id $=24604231$

33. Obraztsov, V. A. (1982). Преступления, связанные с профессиональной деятельностью как объект криминалистического исследования [Prestupleniya, svyazannyye s professionalnoy deyatelnostyu kak obyekt kriminalisticheskogo issledovaniya]. Voprosy borby s prestupnostyu, 36, 91-100.

34. Reanimation Package of Reforms (2019, March). Україна має зосередитися на запобіганні корупиї, а не покаранні Великий антикорупційний 
аналіз [Ukraina maie zoseredytysia na zapobihanni koruptsii, a ne pokaranni - Velykyi antykoruptsiinyi analiz]. Retrieved from https://rpr.org.ua/news/ ukrajina-maje-zoseredytysyana-zapobihanni-koruptsijia-ne-pokaranni-velykyjantykoruptsijnyj-analiz/

35. Rettenmaier and Adick. Law firm. (n. d.). Retrieved from https:// rettenmaier-adick.de/?lang=en

36. Saienko, M. (2015).

Відповідальність перших осіб перед клієнтами: ілюзія чи реальність? [Vidpovidalnist pershykh osib pered kliientamy: iliuziia chy realnist?]. Yuryst $i$ Zakon, 8, 28-39.

37. Seredniak, T. K. (2018). Україна проти корупиіі: Економічний фронт. Економічна оцінка антикорупиійних заходів y 2014-2018 pp. [Ukraina proty koruptsii: Ekonomichnyi front. Ekonomichna otsinka antykoruptsiinykh zakhodiv u 2014-2018 rr.] (68 p.). Dnipro.

38. Stashysa, V. V., \& Tatsiia, V. Ya. (Eds.) (2010). Кримінальне право України: Особлива частина: підручник [Kryminalne pravo Ukrainy: Osoblyva chastyna: pidruchnyk] (pp. 186-187). Kharkiv: Pravo. Retrieved from http://library.nlu.edu.ua/ POLN_TEXT/KNIGI-2010/ UgolovPravoOsob.pdf

39. Stechyshyn, T. B., \& Didyk, M. M. (2016). Забезпечення стабільності банківської системи в умовах фінансової кризи [Zabezpechennia stabilnosti bankivskoi systemy $\mathrm{v}$ umovakh finansovoi kryzy]. Ekonomika i Suspilstvo, 16, 808-818. Retrieved from http:// economyandsociety.in.ua/ journal/16_ukr/123.pdf

40. The Bank Secrecy Act (BSA). (1970). In Wikipedia. Retrieved from https://en.wikipedia.org/ wiki/Bank_Secrecy_Act

41. The Criminal Code of Finland. (2015). Retrieved from https:// www.legislationline.org/ download/action/download/ id/6375/file/Finland_CC_1889_ am2015_en.pdf

42. The Money Laundering Control Act. (1986). In Wikipedia. Retrieved from https:// en.wikipedia.org/wiki/Money_ Laundering_Control_Act

43. The National Anti-Corruption Bureau of Ukraine (NABU) (n. d.) Retrieved from https://nabu.gov. ua/en

44. The State Financial Monitoring Service of Ukraine (n. d.) Запобігання корупиіі [Zapobihannya koruptsiyi]. Retrieved from http://www. sdfm.gov.ua/articles.php?cat_ $\mathrm{id}=218$ \&lang $=\mathrm{uk}$

45. Tuliai, E. (2010). Финансовоправовое регулирование банковской деятельности в Российской Федераици [Finansovo-pravovoye regulirovaniye bankovskoy deyatelnosti $v$ Rossiyskoy Federatsii] (184 p.). Tomsk: NTL.

46. Ulybina, V. O. (2014). Кримінальна відповідальність за доведення до банкрутства [Kryminalna vidpovidalnist za dovedennia do bankrutstva] (Ph.D.

Thesis) (255 p.). Kyiv.

47. Uskov, D. Yu. (2013). Финансовая стабильность банков: методологический подход [Finansovaya stabilnost bankov: metodologicheskiy podkhod]. Sotsialno-ekonomicheskiye yavleniya i protsessy, 5(051), 200 204.

48. Verkhovna Rada of Ukraine. (2001a). Кримінальний кодекс України [Kryminalnyi kodeks Ukrainy]. Vidomosti Verkhovnoi Rady Ukrainy, 25-26, st. 218-1.

49. Verkhovna Rada of Ukraine. (2001b). Закон України № 2121III. Про банки і банківську діяльність [Zakon Ukrainy No. 2121-III. Pro banky i bankivsku diialnist]. Vidomosti Verkhovnoi Rady Ukrainy, 5-6, st. 30. Retrieved from https://zakon.rada.gov.ua/ laws/show/2121-14

50. Verkhovna Rada of Ukraine. (2014). Закон України № 1700VII "Про запобігання корупції" [Zakon Ukrainy No. 1700-VII "Pro zapobihannia koruptsii"]. Vidomosti Verkhovnoi Rady (VVR), 49, st. 2056. Retrieved from https://zakon.rada.gov.ua/laws/ show/1700-18\#n737

51. Volchenko, N., \& Klietsova, N. (2019, March 23). Modern mechanisms of control and strategic benchmarks of banking security. Assesment of the level of development of the country infrastructure in the context of innovative economy. Materials of the Internatinal Scientific and Practial Conference (pp. 3740). Dnipro: Scientific Union "Perspektyva". 